\title{
Milk fatty acid composition and associated rumen lipolysis and fatty acid hydrogenation when feeding forages from intensively managed or semi-natural grasslands 1
}

\author{
Marta LOURENÇO ${ }^{\mathrm{a}}$, Bruno VlAEMINCK ${ }^{\mathrm{a}}$, Martine BRUINENBERG ${ }^{\mathrm{b} *}$, \\ Daniel DEMEYER ${ }^{\mathrm{a}}$, Veerle FIEVEZ ${ }^{\mathrm{a} * *}$
}

\begin{abstract}
${ }^{\text {a }}$ Laboratory for Animal Nutrition and Animal Product Quality, Faculty of Bioscience Engineering, Ghent University, Proefhoevestraat 10, 9090 Melle, Belgium

${ }^{\mathrm{b}}$ Nutrition and Food, Animal Sciences Group, Wageningen, UR, Edelhertweg 15, 8200 AB Lelystad, The Netherlands
\end{abstract}

(Received 3 August 2004; accepted 22 July 2005)

\begin{abstract}
In order to evaluate the effect of replacing intensive forage by semi-natural grassland products on rumen lipid metabolism and milk fatty acid composition, four lactating and rumen canulated Holstein cows were used in a $4 \times 4$ Latin square design. Four different diets were fed: diet 100 IM - 100\% intensively managed silage (IM), diet 20 SPP $-80 \%$ IM plus $20 \%$ semi-natural but species poor silage (SPP), diet 60 SPP - 40\% IM plus 60\% SPP and diet 60 SPR - 40\% IM plus $60 \%$ semi-natural species rich silage (SPR). The silages showed significant differences in total fat content and in proportions of C18:2 n-6 and C18:3n-3. Despite the reduced dietary supply of C18:3 $\mathrm{n}-3$ with diets 60 SPP and 60 SPR, differences in milk C18:3 n- 3 were small, suggesting higher recoveries of C18:3n-3. Presumably, the latter are related to a higher transfer efficiency of C18:3 n-3 from the duodenum to the mammary gland, since rumen biohydrogenation, estimated from rumen pool size and first order rumen clearance kinetics, were similar among diets. CLA c9t11 in milk from cows fed diet 60 SPR were almost doubled compared to feeding one of the other diets. This has been related to the partial inhibition of rumen biohydrogenation of C18:3n-3 and/or C18:2 n-6, as suggested by the increased proportions of hydrogenation isomers and reduced stearic acid proportions in rumen pool samples. In conclusion, the results suggest that the use of semi-natural grasslands in the diet of the animals reduce to some extent complete rumen biohydrogenation, which leads to an increase in milk CLA.
\end{abstract}

grasslands / hydrogenation / rumen / milk fatty acids / CLA

\footnotetext{
${ }^{1}$ Part of the results on milk fatty acids were presented at the 19th General Meeting of the European Grassland Federation, 'Multifunction Grasslands' . (Fievez V., Vlaeminck B., Raes K., Chow T.T., De Smet S., Demeyer D., Bruinenberg M.H., Dietary and milk fatty acid composition in relation to the use of forages from semi-natural grasslands, Grassland Science in Europe, Vol. VII, 2002, pp. 558-559.)

* Current address: Nutrient Management Institute NMI, PO Box 250, 6700 AG Wageningen, The Netherlands.

** Corresponding author: veerle.fievez@UGent.be
} 
Résumé - La composition en acides gras du lait, la lipolyse et l'hydrogénation dans le rumen chez les vaches recevant des fourrages provenant de prairies intensives ou semi-naturelles. Pour évaluer l'effet d'un fourrage, provenant d'une prairie semi-naturelle vs. prairie intensive, sur la composition en acides gras du lait et le métabolisme des lipides dans le rumen, quatre vaches laitières Holstein, munies d'une cannule du rumen, ont été utilisées dans un schéma en carré latin $4 \times 4$. Quatre régimes différents ont été employés : régime $100 \mathrm{IM}$ - $100 \%$ ensilage d'herbe en culture intensive (IM), régime 20 SPP - $80 \%$ IM plus $20 \%$ ensilage d'herbe semi-naturelle mais d'une biodiversité pauvre (SPP), régime $60 \mathrm{SPP}-40 \%$ IM plus $60 \%$ SPP et régime $60 \mathrm{SPR}-40 \%$ IM plus $60 \%$ ensilage d'herbe semi-naturelle d'une biodiversité riche (SPR). Des différences significatives ont été observées aussi bien dans les taux de lipides totaux que pour les proportions de C18:2 n-6 et de C18:3 n-3 dans les ensilages. En dépit d'une ingestion réduite de C18:3 n-3 avec les régimes 60 SPP et 60 SPR, les différences de concentration en C18:3n-3 dans le lait étaient faibles. Ces résultats sont vraisemblablement dus à une plus grande efficacité de transfert du C18:3 n-3 du duodénum vers la glande mammaire, puisque l'hydrogénation dans le rumen, estimée à partir du pool des acides gras dans le rumen et la cinétique de premier ordre de disparition de C18:3 n-3, était similaire parmi les régimes. Les taux de CLA c9t11 dans le lait des vaches soumises au régime 60 SPR étaient approximativement deux fois plus élevés comparativement aux autres régimes. Ceci est à relier à une réduction partielle de l'hydrogénation de C18:3 n-3 et C18:2 n-6, comme le suggèrent les proportions élevées des isomères issus de l'hydrogénation et les proportions réduites d'acide stéarique dans le pool du rumen. En conclusion, nos résultats suggèrent que l'utilisation de prairies semi-naturelles dans le régime d'animaux laitiers réduit l'hydrogénation complète dans le rumen aboutissant à une augmentation du CLA dans le lait.

prairies / hydrogénation / rumen / acides gras laitiers / CLA

Abbreviation key: CLA - Conjugated Linoleic Acid; FAME - Fatty Acid Methyl Esters; IM - Intensively Managed ryegrass silage; PUFA - Poly-Unsaturated Fatty Acids; SFA - Saturated Fatty Acids; SPP - Species Poor silage; SPR - Species Rich silage.

\section{INTRODUCTION}

In the last decades, concerns have been raised about the role of fatty acids in human health. In this respect, ruminant products have been criticized for their relatively high levels of medium chain saturated fatty acids (SFA) and low levels of poly-unsaturated fatty acids (PUFA). These are the result of de novo synthesis of short and medium chain fatty acids in the mammary gland, from acetate and $\beta$-hydroxy-butyrate and of extensive rumen biohydrogenation of dietary PUFA, respectively. Hydrogenation intermediates and their derived products, among which is conjugated linoleic acid (CLA), are, however, relatively unique to ruminant products, with dairy products providing two thirds of the daily CLA intake [27]. Despite extensive rumen hydrogenation, the content of n-3 fatty acids and CLA in dairy products is largely determined by the cow's diet. For instance, the levels of
C18:3 n-3 and CLA in milk suffer seasonal variations, being higher in the summer than in the winter [20-22]. This might be due to differences in dietary supply of precursor fatty acids, that is C18:3 n-3 and/or C18:2 $\mathrm{n}-6$, due to for example variation in the forage to concentrate ratio [38,39], conserved vs. fresh grass [18, 25, 27], maize silage vs. grass silage [9], linseed supplementation [24], grazing period [30] or clover vs. grass silage [11]. However, higher levels of C18:3 n-3 acid in milk and beef upon the (partial) replacement of grass by clover silages could not be attributed to differences in the supply of the precursor fatty acid, but it is hypothesized that this is related to higher rumen outflow rates of white clover and the presence of lipase inhibitory compounds in red clover [10, 12 , 28]. Moreover, diverse highland and mountain pastures showed a higher potential to stimulate milk CLA secretion than legumes and grasses of the lowland pastures $[7,8$, 
26]. Indeed, essential oils in some herbs of the more diverse grassland species have been reported to show antimicrobial effects [3], comparable to ionophores [16]. The latter, e.g. monesin, are described to lower complete rumen biohydrogenation to stearic acid, leading to the accumulation of hydrogenation intermediates [23, 43].

Thus, the objectives of this study were to evaluate the effect of replacing intensive forage by semi-natural grassland products on milk fatty acid composition, and to examine whether these differences could be linked to changes in rumen fatty acid metabolism.

\section{MATERIALS AND METHODS}

\subsection{Experimental design}

The experiment was carried out as described by Bruinenberg et al. [2]. Briefly, four lactating and rumen canulated Holstein cows $(647 \pm 69 \mathrm{~kg}$ at the start of the trial), 20 to $25 \mathrm{~kg}$ milk per day $(249 \pm$ 76 days in lactation at the beginning of the experiment) were used. The experiment was carried out from May until August 2001 and was designed as a Latin square. Each experimental period lasted three weeks, including an adaptation period of two weeks and a sampling period for the last week. The cows were fed twice daily, receiving $40 \%$ of the daily dry matter (DM) intake in the morning (6:00) and 60\% in the evening (16:00).

\subsection{Diets}

As described by Bruinenberg et al. [2], four different diets were used, containing forages with different combinations of three grassland silages. The latter were obtained from one intensively managed grassland (IM) and two semi-natural grasslands: one species poor (SPP) composed (proportions expressed on a DM basis) mainly (95.9\%) of mature grasses, of which Lolium perenne represented $5.9 \%$ [other grass species present in the silage were Holcus lanatus (35.5\%), Poa trivialis (13.9\%), Alopecurus geniculatus (13.3\%), Agrostis stolonifera (12.3\%)], $0.03 \%$ legumes and $4.0 \%$ non-leguminous herbs [mainly Ranunculus repens $(3.2 \%)$ ]; and one species rich (SPR) consisting of $34 \%$ non-leguminous herbs (4.1\% Anthiscus sylvestris, 3.9\% Ranunculus acris, $3.9 \%$ Galium mollugo, 3.8\% Crepis biennis, 3.6\% Cirsium arvense, $3.4 \%$ Plantago lanceolata, 3.3\% Achillea millefolium, 3.1\% Heracleum sphondylium), $11 \%$ legumes (4.9\% Lathyrus pratensis, $2.9 \%$ Trifolium pratense, $1.7 \%$ Trifolium repens) and $55 \%$ grasses (13.2\% Arrhenatherum elatius, $4.1 \%$ Lolium perenne, $3.8 \%$ Alopercurus pratensis, $3.6 \%$ Dactylis glomerata, 3.3\% Agrostis stolonifera, 3.1\% Festuca rubra, 1.8\% Poa trivialis). Diet one (100 IM) was composed of IM silage only; the second diet (20 SPP) consisted of $80 \%$ IM silage and 20\% SPP silage; diet three (60 SPP) consisted of $40 \%$ IM silage and 60\% SPP silage and the fourth diet (60 SPR) consisted of $40 \%$ IM silage and $60 \%$ SPR silage. The pasture of SPP was managed to encourage nesting of birds, and was fertilized on March 10th 2000 with $20 \mathrm{~m}^{3}$ cattle slurry $\cdot \mathrm{ha}^{-1}$. In order to allow birds to complete nesting, harvesting of this grassland was not allowed before June 7th 2000, when cutting of the grasses took place. The pasture of SPR was part of a nature reserve and had not been fertilized since approximately 1980 . In order to maintain biological diversity, harvesting of the grasslands was not allowed before June 15 th and hence the herbage was harvested on June 21st 2000. The pasture of IM was from a sward growing on a clay soil that received $112 \mathrm{~kg} \mathrm{~N} \cdot \mathrm{ha}^{-1}$ on March $22 \mathrm{nd}$ 2000 and was harvested on May 5th 2000, in order to achieve a high quality of the forage. The forages were pre-wilted $(<72 \mathrm{~h})$ until a DM content of $600-750 \mathrm{~g} \cdot \mathrm{kg}^{-1}$ and were ensiled in big bales of 400-600 kg. Table I represents some characteristics of the silages in terms of their chemical composition, net energy content and fatty acid composition. In addition to the silages (mean intake of $13.2 \mathrm{~kg} \mathrm{DM} \cdot \mathrm{day}^{-1}$ ), the cows were 
fed $4.5 \mathrm{~kg}$ of concentrate per day (chemical and fatty acid composition shown in Tab. II). Feed refusals were weighed daily and feed intake was measured during $48 \mathrm{~h}$, in the measuring week [1]. Negative protein balances were avoided and negative energy balances did not occur since all cows were in an advanced stage of lactation.

\subsection{Measurements and sampling}

The silage sampling procedure was as described by Bruinenberg et al. [2]. Briefly, the samples of the silage mixtures were taken immediately after mixing for feeding and stored at $-18^{\circ} \mathrm{C}$. One composite sample of silage per experimental period was used for further analysis $(n=4)$. The concentrate was sampled once per experimental period, stored frozen $\left(-18^{\circ} \mathrm{C}\right)$ and one composite sample (from the four periods) was used for further analysis $(\mathrm{n}=1)$.

Consecutive milk samples were collected at two morning and two evening milkings, on days 2 and 3 of the measuring week. The samples were stored at $-18{ }^{\circ} \mathrm{C}$ with potassium dichromate (1 tablet per $50 \mathrm{~mL}$ ) as a preservative (Merck, Darmstad, Germany).

Rumen contents were completely evacuated manually at 4:00, 10:00 and 20:00 of day 4 and at 9:00 of day 5 of the measuring week, and the animals were deprived of food between the latter 2 evacuations [ 40 , 44]. The contents were mixed thoroughly and a sample of $1 \mathrm{~kg}$ was taken, which was then freeze-dried and stored at ambient temperature until analysis.

\subsection{Analysis}

The lipids of feed samples were extracted following the method of Folch et al. [15] with some adaptations as described by Raes et al. [36]. Briefly, from the frozen diet samples, a representative subsample of $5 \mathrm{~g}$ was weighed in an extraction tube and chloroform/methanol (C/M) (2/1 v/v) and $10 \mathrm{mg}$ of internal standard (heptadecanoic acid, Sigma Bornem, Belgium) were added. The samples were homogenized by an ultra-turrax mixer (Ultra-Turrax T25, IKA-Labortechnik, Belgium) and were extracted overnight. After extraction, the samples were methylated [36]. Fatty acid methyl esters (FAME) were identified by gas-liquid chromatography as described by Raes et al. [36].

Fatty acids in rumen samples $(2.5 \mathrm{~g}$ of freeze-dried material) were extracted overnight with $30 \mathrm{~mL}$ of chloroform/methanol (C/M) (2/1 v/v), $20 \mathrm{~mL}$ of distilled water and $10 \mathrm{mg}$ of nonadecanoic acid (Sigma, Bornem, Belgium) used as the internal standard. The extracts were centrifuged for $15 \mathrm{~min}$ at $1821 \times \mathrm{g}$. This procedure was repeated twice by adding $20 \mathrm{~mL} \mathrm{C/M} \mathrm{(2/1}$ $\mathrm{v} / \mathrm{v})$. The extracts were combined, washed once with distilled water to avoid the formation of methyl esters during further analysis of the samples and brought to a final volume of $100 \mathrm{~mL}$ with $\mathrm{C} / \mathrm{M}(2 / 1 \mathrm{v} / \mathrm{v})$. Fatty acids were methylated with $\mathrm{NaOH}$ in methanol $\left(0.5 \mathrm{~mol} \cdot \mathrm{L}^{-1}\right)$ followed by $\mathrm{HCl}$ in methanol $(1 / 1 \mathrm{v} / \mathrm{v})$ at $50^{\circ} \mathrm{C}$ [36]. Fatty acid methyl esters were extracted twice with $2 \mathrm{~mL}$ of hexane and pooled extracts were evaporated to dryness under $\mathrm{N}_{2}$. The residue was dissolved in $1 \mathrm{~mL}$ hexane and analyzed by gas chromatography [37].

Milk samples were extracted according to the isomethod (ISO-3889) using Rosein Gotlieb extraction tubes, in three steps [45]. In the first step, samples were extracted with ammonium hydroxide solution, ethanol, diethyl ether and petroleum ether. In the second step, samples were extracted with ethanol, diethyl ether and petroleum ether. In the final extraction step, the solvents used were diethyl ether and petroleum ether. Extracts were combined, evaporated, methylated and analysed separately for short chain fatty acids (C4:0-C10:0) and medium and long chain fatty acids (C12:0 C24:0). Standard curves were used to determine the response factors for milk short chain fatty acids, taking into account tridecanoic acid (Sigma Bornem, Belgium) as the internal standard, whereas the other fatty acids were quantified with nonadecanoic 
acid as the internal standard (Sigma Bornem, Belgium) [45].

\subsection{Chromatography}

FAME were analyzed on a Hewlett-Packard 6890 gas chromatograph (Hewlett-Packard Co., Brussels, Belgium) with a CP-Sil88 column for FAME $(100 \mathrm{~m} \times 0.25 \mathrm{~mm} \times$ $0.2 \mu \mathrm{m}$; Chrompack Inc., Middelburg, The Netherlands). For more detailed information about the GC analysis of feed and rumen fatty acids we refer to Raes et al. [37] and to Vlaeminck et al. [45] for milk fatty acids. Separation of the isomers C18:1 t10 and $\mathrm{C} 18: 1 \mathrm{t} 11$ was possible in milk samples but not in rumen samples, due to the status of the GC column, which was new at the time of analysis of the milk samples, compared to the analysis of the rumen samples, which took place 2 to 3 months later.

\subsection{Calculations}

1. Calculations of C18:3 n-3 biohydrogenation rates and duodenal flow of C18:3 n-3 were based on the afternoon intake (at 16:00), on the clearance rate as estimated from the intake at 16:00 - which equals the C18:3 n-3 amount at $0 \mathrm{~h}-$ and the rumen evacuations at $4 \mathrm{~h}$ (20:00) and $17 \mathrm{~h}$ (9:00) after feeding and on the effective hydrogenation based on hydrogenation and passage rates: (a) Clearance rate: The rumen clearance rate of a compound represents both the degradation as well as the passage rate [40]. Applied to PUFA, clearance rates $\left(\mathrm{k}_{\mathrm{c}}\right)$ of PUFA can be assumed to represent both the hydrogenation as well as the passage rate: $\mathrm{k}_{\mathrm{c}}=\mathrm{k}_{\mathrm{h}}+\mathrm{k}_{\mathrm{p}}$, where $\mathrm{k}_{\mathrm{h}}$ is the hydrogenation rate and $k_{p}$ is the passage rate. The clearance rate was estimated based on rumen pool size and first order rumen clearance kinetics as follows: $\mathrm{C}=\mathrm{C}_{0} \times \mathrm{e}^{(-\mathrm{kc} \times \mathrm{t})}$, where $\mathrm{C}$ is the amount of $\mathrm{C} 18: 3 \mathrm{n}-3$ remaining in the rumen $(\mathrm{g})$ at time $\mathrm{t}, \mathrm{C}_{0}$ is the intake of $\mathrm{C} 18: 3 \mathrm{n}-3(\mathrm{~g}), \mathrm{k}_{\mathrm{c}}$ is the clearance rate $\left(\% \cdot \mathrm{h}^{-1}\right)$ and $t$ is the time (h). Curve fitting was based on $\mathrm{C} 18: 3$ intake at 16:00 $(\mathrm{t}=0 \mathrm{~h})$ and rumen C18:3 n-3 pool size (C18:3 n-3 concentra- tion $\times$ rumen volume $)$ at 20:00 ( $\mathrm{t}=4 \mathrm{~h})$ and 9:00 ( $\mathrm{t}=17 \mathrm{~h})$; (b) Hydrogenation rate: The hydrogenation rate is calculated by subtracting the passage rate from the clearance rate, assuming the passage rate to be equal to the Acid Detergent Lignin (ADL) clearance rate [40]; (c) Effective biohydrogenation: The effective biohydrogenation of C18:3 n-3 was then calculated as follows: effective hydrogenation $\left(\mathrm{g} \cdot \mathrm{d}^{-1}\right)=\mathrm{C} 18: 3 \mathrm{n}-3$ intake $\left(\mathrm{g} \cdot \mathrm{d}^{-1}\right) \times\left[\mathrm{k}_{\mathrm{h}} /\left(\mathrm{k}_{\mathrm{h}}+\mathrm{k}_{\mathrm{p}}\right)\right]$ [33]; (d) Relative biohydrogenation: The percentage of biohydrogenation can then be calculated as follows: \% Biohydrogenation $=$ [effective hydrogenation $\left(\mathrm{g} \cdot \mathrm{d}^{-1}\right) / \mathrm{C} 18: 3 \mathrm{n}-3$ intake $\left.\left(\mathrm{g} \cdot \mathrm{d}^{-1}\right)\right] \times 100$; (e) daily duodenal flow of C18:3 n-3: Based on the effective biohydrogenation, the daily amount of C18:3 n-3 passing to the duodenum was calculated as follows: C18:3 n-3 $\left(g \cdot d^{-1}\right)=C 18: 3 n-3$ intake $\left(\mathrm{g} \cdot \mathrm{d}^{-1}\right)$ - effective hydrogenation $\left(\mathrm{g} \cdot \mathrm{d}^{-1}\right)$, where $\mathrm{C} 18: 3 \mathrm{n}-3_{\mathrm{d}}$ is the amount of C18:3 n-3 that leaves the rumen into the duodenum.

2. Recovery of C18:2 n-6 and C18:3 $\mathrm{n}-3$ in milk were calculated based on the amount of these fatty acids in the milk and their intake from the silage and the concentrate, with (a) milk secretion calculated as follows: FA milk $\left(\mathrm{g} \cdot \mathrm{d}^{-1}\right)=$ [FA milk $(\%$ FAME $) \times$ milk production $\left(\mathrm{kg} \cdot \mathrm{d}^{-1}\right) \times$ milk fat $(\%) \times 1000] / 10000$; (b) intake as follows: FA intake $\left(\mathrm{g} \cdot \mathrm{d}^{-1}\right)=[($ FA silage $(\%$ FAME $) \times$ silage intake $\left(\mathrm{kg} \cdot \mathrm{d}^{-1}\right) \times \mathrm{FA}$ silage $\left(\mathrm{g} \cdot \mathrm{kg}^{-1}\right.$ $\mathrm{DM})) / 100]+[(\mathrm{FA}$ conc. $(\% \mathrm{FAME}) \times$ conc. intake $\left(\mathrm{kg} \cdot \mathrm{d}^{-1}\right) \times \mathrm{FA}$ conc. $\left.\left(\mathrm{g} \cdot \mathrm{kg}^{-1} \mathrm{DM}\right)\right) /$ 100] and finally the proportion of dietary C18:2 n-6 or C18:3 n-3 recovered in the milk as: Recovery feed $(\%)=\left[\mathrm{FA}\right.$ milk $\left(\mathrm{g} \cdot \mathrm{d}^{-1}\right) /$ FA intake $\left.\left(\mathrm{g} \cdot \mathrm{d}^{-1}\right)\right] \times 100$. The transfer efficiency of C18:3 n-3 and C18:2 n- 6 from the duodenum to the milk was calculated as follows: Recovery duodenum $(\%)=[\mathrm{FA}$ milk $\left(\mathrm{g} \cdot \mathrm{d}^{-1}\right) /$ FA duodenum $\left.\left(\mathrm{g} \cdot \mathrm{d}^{-1}\right)\right] \times 100$.

3. The ratios C14:1 c9/C14:0, C16:1 c9/ C16:0 and CLA c9t11/C18:1 t11 give some measure of the activity of the $\Delta^{9}$-desaturase enzyme [14, 29]. Nevertheless, recently, Palmquist et al. [34] proposed a nutritional 
model which allows the calculation of the endogenous CLA c9t11 synthesis in the mammary gland, from the amount of CLA and C18:1 $\mathrm{t} 11$ measured in the milk, according to the model: CLATot $_{\text {in }}=$ CLArum $_{\mathrm{i}}+$ $\left\{\left[\mathrm{k}_{\mathrm{i}} /\left(1-\mathrm{k}_{\mathrm{i}}\right)\right] \times\right.$ VATis $\left._{\text {in }}\right\}$, where CLATot in $_{\text {in }}$ is the total amount of CLA of the milk of the nth animal on the ith diet; CLArum $_{i}$ is the milk CLA from ruminal origin; $\mathrm{k}_{\mathrm{i}}$ is the proportion of total C18:1 t11 that is converted to CLA c9t11 in the milk when fed the ith

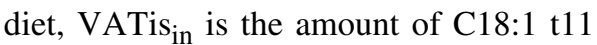
measured in milk and with amounts of all fatty acids expressed as g per $100 \mathrm{~g}$ total fatty acids in the milk. Statistically this equation has the form of a simple regression: CLATot ${ }_{\mathrm{ijn}}=\mathrm{B}^{0}{ }_{\mathrm{ij}}+\mathrm{B}^{1}{ }_{\mathrm{ij}}$ VATis $_{\mathrm{ijn}}+\xi_{\mathrm{in}}$, where, $\mathrm{B}^{0}{ }_{\mathrm{i}}$ is an intercept specific to diet, $\mathrm{B}^{1}{ }_{\mathrm{i}}$ is a slope specific to diet, and $\xi_{\text {in }}$ is an error term. In fact, $\mathrm{B}^{0}{ }_{\mathrm{i}}$ corresponds to CLArum $_{\mathrm{i}}$ and $\mathrm{k}_{\mathrm{i}}$ can then be calculated from $\mathrm{B}^{1}{ }_{\mathrm{i}}$ as follows: $\mathrm{k}_{\mathrm{i}}=\mathrm{B}^{1}{ }_{\mathrm{i}} /\left(1+\mathrm{B}^{1}{ }_{\mathrm{i}}\right)$.

\subsection{Statistics}

A split plot analysis for repeated measures (time sampling at 4:00, 10:00 and 20:00 of day 4 and 9:00 of day 5 of the measuring week) was used to evaluate the effect on rumen fatty acids content and composition of dietary treatments, variations between animals and the interaction between diets and animals. The effect of sampling time was evaluated from the "within-subject-effect" (Wilks lambda value is presented). The diets (100 IM, 20 SPP, 60 SPP and 60 SPR) and the animals (1, 2, 3 and 4) were introduced as "between-subject-factors" and their effects evaluated from the "betweensubject-effects", using orthogonal contrasts to evaluate dietary effects. Three orthogonal contrasts were applied: (1) diet 100 IM vs. the other 3 diets (20SPP, 60SPP, 60SPR), to compare $100 \%$ intensively managed ryegrass silage with combined silages of IM and another forage type; (2) diet 20 SPP vs. diets 60 SPP and 60 SPR, to evaluate the effect of proportion of semi-natural grassland in the diet; (3) diet 60 SPP vs. diet
$60 \mathrm{SPR}$, to compare a species poor silage and a species rich silage.

A general linear ANOVA-model was used to evaluate the effect of diet, animal, sampling time and experimental period on milk fatty acid content and composition, according to:

$$
\mathrm{Y}_{\mathrm{ijkl}}=\mathrm{D}_{\mathrm{i}}+\mathrm{S}_{1}+\mathrm{C}_{\mathrm{j}}+\mathrm{P}_{\mathrm{k}}+\xi_{\mathrm{ijkl}}
$$

where $Y_{i j k l}$ is the individual observation, $D_{i}$ the effect of diet (fixed factor), $S_{1}$ the effect of sampling time (morning vs. evening sampling) (fixed factor), $C_{j}$ the animal effect (random factor), $\mathrm{P}_{\mathrm{k}}$ the effect of experimental period (random factor) and $\xi_{\mathrm{ijk}}$ the residual error. Again the same three orthogonal contrasts as described before were applied.

Significances presented in Table $\mathrm{V}$ for $\mathrm{k}_{\mathrm{i}}$ were accessed comparing the $95 \%$ confidence intervals for each slope of each diet. The comparisons were made in the same way as for the orthogonal contrasts, that is diet 100 IM vs. the other 3 diets; diet 20 SPP vs. diets $60 \mathrm{SPP}+60 \mathrm{SPR}$ and diet $60 \mathrm{SPP}$ vs. diet 60 SPR.

All statistical analyses were performed using SPSS 11.0 (SPSS software for Windows, release 11.0, SPSS, Inc., USA). Effects with $P<0.05$ were considered significant.

\section{RESULTS}

\subsection{Chemical composition and fatty acid characteristics of the diets}

As shown in Table I, silages and diets had similar organic matter contents. The crude protein was higher for diet 100 IM and decreased as the percentage of intensive ryegrasss silage in the diet diminished (Tab. I). Net energy content of silage 60 SPR was $20 \%$ lower than that of 100 IM silage. Nevertheless, no negative energy balances occurred during the experiment, since the cows were in late stages of lactation $(249 \pm$ 76 days of lactation at the beginning of the experimental period). Indeed, the net energy supplied $\left(115,114,105\right.$ and $110 \mathrm{MJ} N E \cdot \mathrm{d}^{-1}$ 
Table I. Chemical composition, net energy content, fatty acid content and proportion of predominant fatty acids of the mixed silages used in the four dietary treatments.

\begin{tabular}{lccccc}
\hline Diet & $100 \mathrm{IM}$ & 20 SPP & 60 SPP & 60 SPR & SE \\
\hline Intake of silage $\left(\mathrm{kg} \mathrm{DM} \cdot \mathrm{d}^{-1}\right)$ & 13.9 & 13.6 & 12.2 & 13.0 & 1.20 \\
DM $\left(\mathrm{g} \cdot \mathrm{kg}^{-1}\right.$ fresh material) & 601 & 625 & 674 & 594 & 91.8 \\
Chemical composition $\left(\mathrm{g} \cdot \mathrm{kg}^{-1} \mathrm{DM}\right)$ & & & & & \\
$\quad$ Organic matter & 885 & 889 & 897 & 897 & 1.7 \\
Crude protein & 191 & 181 & 159 & 139 & 1.8 \\
Neutral detergent fiber & 524 & 540 & 568 & 547 & 8.8 \\
Net energy $\left(\mathrm{MJ} \cdot \mathrm{kg}^{-1} \mathrm{DM}\right){ }^{1}$ & 5.9 & 5.6 & 5.0 & 4.7 & 0.08 \\
& & & & & \\
Total fatty acids $\left(\mathrm{g} \cdot \mathrm{kg}^{-1} \mathrm{DM}\right)$ & 15.9 & 14.9 & 11.8 & 13.2 & 0.37 \\
Individual fatty acids $(\%$ of total FAME) & & & & & \\
C16:0 & 14.8 & 15.3 & 16.0 & 15.7 & 0.35 \\
C18:1 & 2.9 & 3.7 & 4.5 & 4.9 & 0.36 \\
C18:2 n-6 & 11.0 & 11.9 & 13.9 & 14.6 & 0.58 \\
C18:3 n-3 & 48.0 & 44.7 & 39.1 & 38.6 & 0.87 \\
\hline
\end{tabular}

${ }^{1}$ Net Energy calculated based on the VEM system [42].

Table II. Chemical composition, total fatty acid content and proportion of predominant fatty acids of the concentrate used in the four dietary treatments.

\begin{tabular}{lccc}
\hline & \multicolumn{3}{c}{ Predominant fatty acids } \\
\hline Intake concentrate $\left(\mathrm{kg} \mathrm{DM} \cdot \mathrm{d}^{-1}\right)$ & 4.5 & Total fatty acids $\left(\mathrm{g} \cdot \mathrm{kg}^{-1} \mathrm{DM}\right)$ & 68.8 \\
$\mathrm{DM}\left(\mathrm{g} \cdot \mathrm{kg}^{-1}\right.$ fresh material $)$ & 874 & Individual fatty acids $(\%$ of total FAME) & \\
Chemical composition & $\left(\mathrm{g} \cdot \mathrm{kg}^{-1} \mathrm{DM}\right)$ & $\mathrm{C} 12: 0$ & 25.9 \\
Organic matter & 907 & $\mathrm{C} 16: 0$ & 13.7 \\
Crude protein & 247 & $\mathrm{C} 18: 1$ & 18.0 \\
Neutral detergent fiber & 311 & $\mathrm{C} 18: 2 \mathrm{n}-6$ & 20.2 \\
Net energy $\left(\mathrm{MJ} \cdot \mathrm{kg}^{-1} \mathrm{DM}\right)^{1}$ & 7.4 & $\mathrm{C} 18: 3 \mathrm{n}-3$ & 1.9 \\
\hline
\end{tabular}

${ }^{1}$ Net Energy calculated based on the VEM system [42].

for diets 100 IM, 20 SPP, 60 SPP and 60 SPR, respectively), always covered the requirements of the animals (104, 97, 97 and $99 \mathrm{MJ} \mathrm{NE} \cdot \mathrm{d}^{-1}$ when fed diets $100 \mathrm{IM}$, 20 SPP, 60 SPP and 60 SPR, respectively). Calculations of net energy were made according to Van Es [42].

It is clear that the dietary supply of C18:3 n-3 mainly originates from the silages whereas both silages and concentrate provide C18:2 n-6 (Tabs. I and II). Moreover, switching from a diet typical of intensive production systems to a more diverse diet, characteristic of extensive systems, increases C18:2 n-6 proportions whereas a decrease is observed in the concentration of C18:3 n-3.

\subsection{Rumen fatty acid characteristics}

Total fatty acid content $\left(\mathrm{mg} \cdot \mathrm{g}^{-1} \mathrm{DM}\right)$ in the rumen decreased with decreasing proportions of intensive ryegrass silage in the 
diet (Tab. III). This also reflects differences in total rumen fatty acid pool size, since total rumen volume did not differ among the diets.

As can be expected, rumen biohydrogenation resulted in an extensive reduction of the proportions of PUFA compared to the PUFA proportions in the diet (Tabs. I and III), as well as in an accumulation of biohydrogenation intermediates, with $\mathrm{C} 18: 1$ $\mathrm{t} 10+\mathrm{t} 11$ being the most abundant intermediate ( 2 to $4 \%$ of total FAME, Tab. III). C18:1 t11, C18:1 t15; C18:1 c15; C18:2 t11c15 and C18:3 c9t11c15 have been suggested as the major hydrogenation intermediates of either C18:2 n-6 and C18:3 n-3. These intermediates represented a significantly higher proportion of total FAME when cows were fed diet 60 SPR $(5.9 \%$ of total FAME) compared to feeding intensive ryegrass silage only (100 IM, 3.9\% of total FAME). Accumulation of these intermediates in the rumen of the cows fed diet 20 SPP and 60 SPP represented $3.9 \%$ and $4.4 \%$ of total FAME, respectively.

Despite the significantly different dietary C18:3 n-3 proportions (Tab. I), cows fed diet 20 SPP and diet 60 SPR showed similar rumen C18:3 n-3 proportions (Tab. III). Nevertheless, the percentage of biohydrogenation, as calculated from fractional rates of biohydrogenation and passage based on the clearance rate of the rumen, remained similar across diets $(93,94,93$ and $94 \%$ for diets 100 IM, 20 SPP, 60 SPP and 60 SPR, respectively).

\subsection{Milk fatty acid characteristics}

Total short chain fatty acids in milk (C4:0 to $\mathrm{C} 10: 0$ ) did not differ significantly when feeding different silages, varying between $9.3 \%$ of total FAME in the milk of cows fed 60 SPR to $9.7 \%$ of total FAME for cows on diet 100 IM (Tab. IV). There was a higher proportion of medium chain fatty acids (C12:0 to C16:0) in the milk of cows fed diet 100 IM (48.8\% of total FAME), compared to feeding a combination of IM silage and natural grassland products (on average $46.8 \%$ of total FAME for diets 20 SPP, 60 SPP and 60 SPR) (Tab. IV). Proportions of C18:0 for diets representing intensive systems (diet $100 \mathrm{IM}$ ) and extensive systems (diet 60 SPR) were very similar: $7.6 \%$ and $7.8 \%$ of total FAME, respectively (Tab. IV).

As for the fatty acids considered health promoting, like C18:1 c9 and PUFA, there was a clearly lower proportion in milk from cows on 100 IM (19.5\% of total FAME) when compared to the other diets, particularly diet 60 SPR ( $21.2 \%$ of total FAME). Despite these higher proportions of "healthy" fatty acids when feeding the 60 SPR, omega-3 fatty acids were proportionally lower for this diet $(0.69 \%$ of total FAME compared to $0.74 \%$ of total FAME for diet 20 SPP and $0.75 \%$ of total FAME for diet $100 \mathrm{IM}$ ) (Tab. IV). Consequently, the $n-6 / n-3$ ratio was slightly higher in the milk of cows fed 60 SPR (1.4) compared to feeding 100 IM (1.1). Nevertheless, differences in milk C18:3 n-3 (0.5\% vs. $0.6 \%$ of total FAME) (Tab. IV) were less than expected from the significantly reduced dietary C18:3 n-3 supply when feeding lower intensive ryegrass silage proportions (Tab. I), which resulted in a higher recovery of dietary C18:3 n-3 in milk when feeding 60 SPP $(7.6 \%)$ and 60 SPR $(7.3 \%)$ compared to diets with higher intensive ryegrass proportions (5.1 to $5.2 \%$ ) (Tab. V). Rumen biohydrogenation intermediates of C18:2 n-6 and C18:3 n-3 (e.g. C18:1 t11, C18:1 c15, C18:1 t15, C18:2 t11c15) in the milk of cows on diet 60 SPR represent $1.54 \%$ of total FAME, whereas proportions in milk of cows fed diet 100 IM were slightly lower $(1.05 \%$ of total FAME) (Tab. IV).

Significant differences were found concerning the CLA isomers in milk upon replacing of the intensive ryegrass silage by SPP. Feeding a more species diverse silage significantly increased the levels of CLA isomers $(0.47 \%$ of total FAME) compared to feeding a species poor silage $(0.28 \%$ of total FAME) (Tab. IV). Estimates of $\Delta^{9}$-desaturase activity in the mammary 


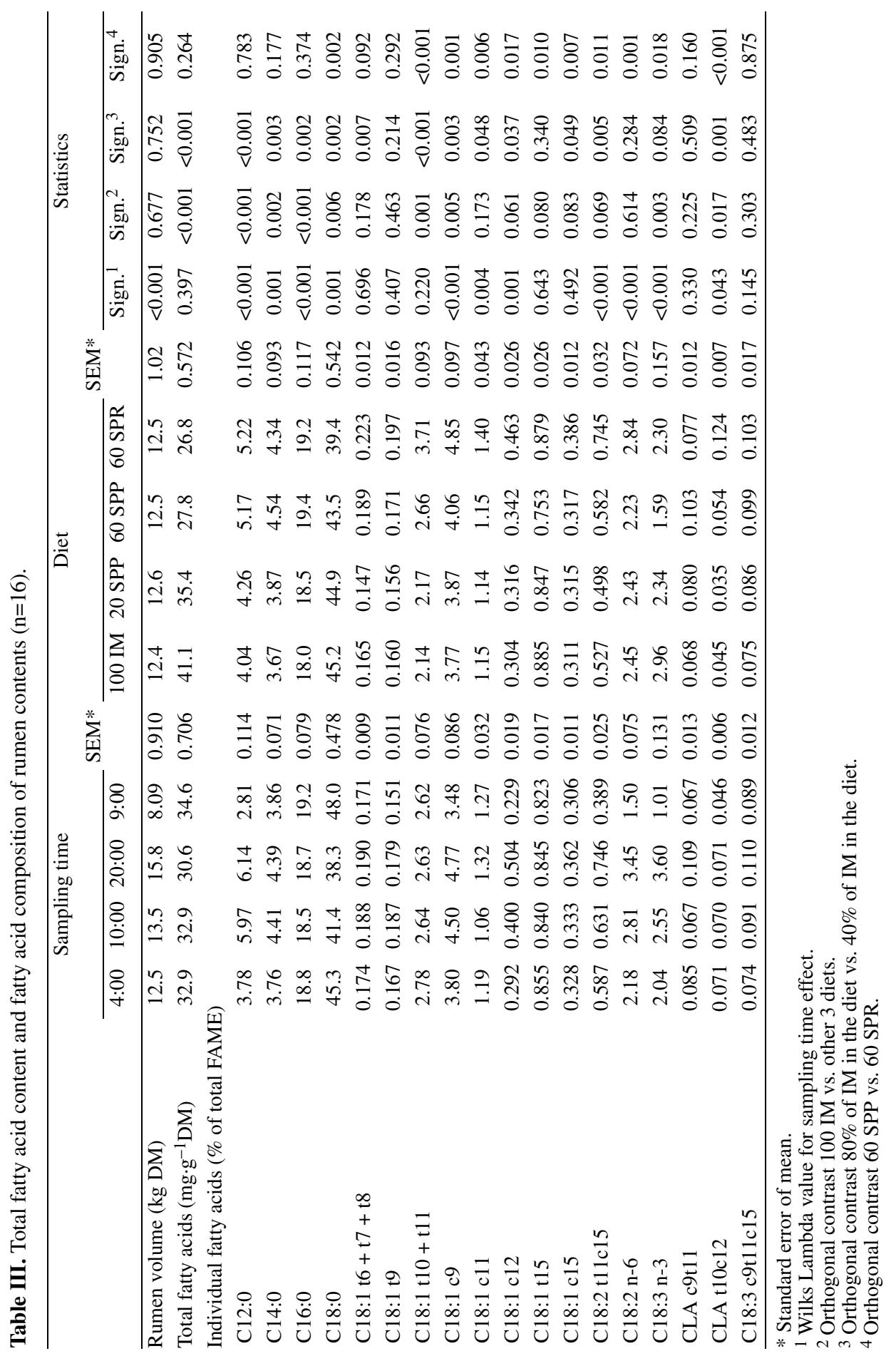


Table IV. Total fatty acid content and composition of milk ( $\mathrm{n}=16)$.

\begin{tabular}{|c|c|c|c|c|c|c|c|c|}
\hline Diet & $100 \mathrm{IM}$ & $20 \mathrm{SPP}$ & $60 \mathrm{SPP}$ & $60 \mathrm{SPR}$ & SEM & Sign. ${ }^{1}$ & Sign. $^{2}$ & Sign. ${ }^{3}$ \\
\hline Milk yield $\left(\mathrm{kg} \cdot \mathrm{d}^{-1}\right)$ & 21.9 & 20.2 & 20.5 & 20.5 & 0.917 & 0.209 & 0.815 & 0.971 \\
\hline Total fat (mg. $\mathrm{g}^{-1}$ milk) & 40.9 & 39.9 & 39.4 & 42.3 & 0.161 & 0.864 & 0.630 & 0.258 \\
\hline \multicolumn{9}{|l|}{$\begin{array}{l}\text { Individual fatty acids } \\
\text { (\% of total FAME) }\end{array}$} \\
\hline $\mathrm{C} 4: 0$ & 3.99 & 4.13 & 4.27 & 4.29 & 0.143 & 0.149 & 0.399 & 0.909 \\
\hline C6:0 & 2.10 & 2.12 & 2.08 & 2.00 & 0.065 & 0.640 & 0.308 & 0.406 \\
\hline C8:0 & 1.19 & 1.18 & 1.11 & 1.03 & 0.037 & 0.068 & 0.024 & 0.139 \\
\hline C10:0 & 2.46 & 2.42 & 2.14 & 1.94 & 0.075 & 0.003 & 0.001 & 0.070 \\
\hline $\mathrm{C} 12: 0$ & 4.23 & 4.14 & 3.83 & 4.09 & 0.076 & 0.029 & 0.071 & 0.025 \\
\hline $\mathrm{C} 14: 0$ & 11.8 & 11.5 & 10.6 & 10.8 & 0.197 & 0.002 & 0.004 & 0.323 \\
\hline $\mathrm{C} 14: 1 \mathrm{c} 9$ & 1.40 & 1.25 & 1.20 & 1.24 & 0.024 & $<0.001$ & 0.333 & 0.303 \\
\hline C16:0 & 30.0 & 29.1 & 28.7 & 29.7 & 0.289 & 0.029 & 0.843 & 0.019 \\
\hline $\mathrm{C} 16: 1 \mathrm{c} 9$ & 1.40 & 1.26 & 1.43 & 1.40 & 0.037 & 0.358 & 0.003 & 0.557 \\
\hline $\mathrm{C} 18: 0$ & 7.63 & 8.47 & 8.20 & 7.83 & 0.157 & 0.007 & 0.028 & 0.105 \\
\hline $\mathrm{C} 18: 1 \mathrm{t} 6+\mathrm{t} 7+\mathrm{t} 8$ & 0.114 & 0.118 & 0.126 & 0.151 & 0.005 & 0.005 & 0.002 & 0.001 \\
\hline $\mathrm{C} 18: 1 \mathrm{t} 9$ & 0.113 & 0.117 & 0.119 & 0.149 & 0.003 & $<0.001$ & $<0.001$ & $<0.001$ \\
\hline C18:1 t10 & 0.106 & 0.099 & 0.116 & 0.151 & 0.007 & 0.063 & 0.001 & 0.002 \\
\hline C18:1 t11 & 0.469 & 0.478 & 0.497 & 0.822 & 0.017 & $<0.001$ & $<0.001$ & $<0.001$ \\
\hline C18:1 c9 & 17.6 & 17.8 & 19.6 & 18.9 & 0.422 & 0.033 & 0.013 & 0.244 \\
\hline C18:1 c11 & 0.370 & 0.423 & 0.561 & 0.512 & 0.023 & $<0.001$ & 0.001 & 0.143 \\
\hline C18:1 c12 & 0.151 & 0.164 & 0.186 & 0.223 & 0.009 & $<0.001$ & $<0.001$ & 0.001 \\
\hline C18:1 c13 & 0.091 & 0.091 & 0.101 & 0.106 & 0.004 & 0.094 & 0.021 & 0.354 \\
\hline C18:1 t15 & 0.338 & 0.325 & 0.266 & 0.361 & 0.005 & 0.002 & 0.099 & $<0.001$ \\
\hline C18:1 c15 & 0.144 & 0.141 & 0.124 & 0.178 & 0.004 & 0.469 & 0.049 & $<0.001$ \\
\hline $\mathrm{C} 18: 2 \mathrm{t} 11 \mathrm{c} 15$ & 0.099 & 0.090 & 0.083 & 0.177 & 0.005 & 0.005 & $<0.001$ & $<0.001$ \\
\hline C18:2 n-6 & 0.798 & 0.805 & 0.857 & 0.948 & 0.024 & 0.018 & 0.004 & 0.015 \\
\hline C18:3 n-3 & 0.612 & 0.604 & 0.549 & 0.590 & 0.013 & 0.062 & 0.045 & 0.038 \\
\hline CLA c9t11 & 0.259 & 0.240 & 0.264 & 0.438 & 0.012 & 0.001 & $<0.001$ & $<0.001$ \\
\hline CLA t10c12 & 0.014 & 0.009 & 0.013 & 0.033 & 0.002 & 0.032 & $<0.001$ & $<0.001$ \\
\hline C20:4 n-6 & 0.031 & 0.029 & 0.022 & 0.032 & 0.002 & 0.302 & 0.420 & 0.007 \\
\hline$C 20: 5 n-3$ & 0.095 & 0.105 & 0.075 & 0.067 & 0.007 & 0.145 & 0.001 & 0.414 \\
\hline C22:6 n-3 & 0.039 & 0.032 & 0.040 & 0.033 & 0.004 & 0.401 & 0.423 & 0.208 \\
\hline
\end{tabular}

${ }_{1}^{1}$ Orthogonal contrast 100 IM vs. other 3 diets.

2 Orthogonal contrast $80 \%$ of IM in the diet vs. $40 \%$ of IM in the diet.

${ }^{3}$ Orthogonal contrast 60 SPP vs. 60 SPR.

gland, based on the ratios $\mathrm{C} 14: 1 \mathrm{c} 9 / \mathrm{C} 14: 0$ and CLA c9t11/C18:1 t11, revealed slightly higher activities when feeding diet 100 IM compared to the other three diets (Tab. V). Nevertheless, calculations of endogenous
CLA c9t11, based on variations upon animals in milk C18:1 t11 and CLA c9t11, revealed the proportion of $\mathrm{C} 18: 1 \mathrm{t} 11$ converted to CLA c9t11 in the mammary gland to be similar for all diets (Tab. V). 
Table V. Estimates of mammary $\Delta^{9}$-desaturase activity and milk recoveries of dietary C18:2 n-6 and C18:3 n-3 (n=16).

\begin{tabular}{lcccccccc}
\hline Diet & 100 IM & 20 SPP & 60 SPP & 60 SPR & SEM & Sign. $^{1}$ & Sign. $^{2}$ & Sign. $^{3}$ \\
\hline Ratio C14:1 c9/C14:0 & 0.121 & 0.109 & 0.114 & 0.114 & 0.002 & 0.001 & 0.107 & 0.939 \\
Ratio C16:1 c9/C16:0 & 0.047 & 0.043 & 0.050 & 0.048 & 0.001 & 0.765 & 0.004 & 0.267 \\
Ratio CLA c9t11/C18:1 t11 & 0.554 & 0.504 & 0.531 & 0.532 & 0.011 & 0.021 & 0.057 & 0.924 \\
$\mathrm{k}_{\mathrm{i}}$ & 0.355 & 0.334 & 0.346 & 0.348 & 0.039 & $>0.05$ & $>0.05$ & $>0.05$ \\
Recovery & & & & & & & & \\
C18:2 n-6 & & & & & & & \\
C18:3 n-3 & 10.9 & 9.55 & 10.9 & 12.2 & 0.599 & 0.948 & 0.032 & 0.177 \\
\hline
\end{tabular}

$\mathrm{k}_{\mathrm{i}}$ - proportion of C18:1 t11 converted into CLA c9t11 in the mammary gland [34].

1 Orthogonal contrast 100 IM vs. the other 3 diets.

2 Orthogonal contrast $80 \%$ of IM in the diet vs. $40 \%$ of IM in the diet.

${ }^{3}$ Orthogonal contrast 60 SPP vs. 60 SPR.

\section{DISCUSSION}

\subsection{Chemical composition of diet and fatty acid characteristics}

Differences in fatty acid composition of milk were not induced by differences in negative energy balance since the net energy supply always covered net energy requirements (maintenance and production), as indicated before [42].

Silage was the major dietary C18:3 n-3 source and the proportions of this fatty acid decreased as the silage became more species diverse. Feeding lower percentages of intensive ryegrass silage reduced the daily intake of C18:3 n-3 (109 g.d $\mathrm{d}^{-1}, 95 \mathrm{~g} \cdot \mathrm{d}^{-1}$, $61 \mathrm{~g} \cdot \mathrm{d}^{-1}$ and $70 \mathrm{~g} \cdot \mathrm{d}^{-1}$ when feeding $100 \mathrm{IM}$, 20 SPP, 60 SPP and 60 SPR respectively), but the recovery of this fatty acid in the milk was higher $(7.63 \%$ and $7.31 \%$ ) in diets 60 SPP and 60 SPR.

\subsection{Rumen fatty acid characteristics}

The fatty acid composition of the rumen contents was in accordance with dietary fatty acid composition for diets 100 IM, 20 SPP and 60 SPP. However, the increased diversity of the 60 SPR diet presumably affected rumen hydrogenation, as suggested by significantly higher accumulation of hydrogenation intermediates for diet 60 SPR, indicating a less complete hydrogenation in the rumen (i.e., reduced accumulation of C18:0 in the rumen). Most probably, substances in herbs prevent complete hydrogenation of $\mathrm{C} 18: 3 \mathrm{n}-3$ and $\mathrm{C} 18: 2 \mathrm{n}-6$, with the conversion of $\mathrm{C} 18: 1 \mathrm{t} 11$ to $\mathrm{C} 18: 0$ being most sensitive to inhibition, as observed before, for example, when supplementing fish oil $[6,31,32]$. In the current study, this was supported by the proportions of these fatty acids in the rumen, both expressed as proportion of total FAME (C18:0 - 39.4\% of total FAME; C18:1 t10+t11 $-3.71 \%$ of total FAME for diet 60 SPR vs. C18:0 $45.2 \%$ of total FAME; C18:1 t10+t11 $2.14 \%$ of total FAME for diet 100 IM) as well as proportion of the sum of C18-FA (C18:0 - 68.3\% of total C18; C18:1 t10+t11 $-8.4 \%$ of total $\mathrm{C} 18$ for diet 60 SPR vs. C18:0 - 75.1\% of total C18; C18:1 t10+t11 $-6.3 \%$ of total C18 for diet 100 IM), with the latter units being the most representative for the evaluation of the extent of biohydrogenation [5]. Although the method used did not allow a distinction between C18:1 t10 and C18:1 t11 isomers, transvaccenic acid (C18:1 t11) can be assumed to be the predominant isomer when feeding grass silage based diets [12], in agreement with our milk fatty acid profiles.

\subsection{Milk fatty acid characteristics}

The higher presence of hydrogenation intermediates in milk when fed the 60 SPR 
diet reinforces the data observed in the rumen contents. Increased CLA c9t11 content in milk of cows fed 60 SPR most probably is provoked by a higher supply of C18:1 t11 [14] in accordance to the observations in the rumen samples. Indeed, CLA is mainly produced in the mammary gland from C18:1 t11 through the activity of $\Delta^{9}$-desaturase enzyme [17]. Presumably, differences in C18:1 t11 supply rather than in $\Delta^{9}$-desaturase enzyme activity determine milk CLA c9t11 concentrations [14], as the C14:1 c9 to C14:0 ratio (0.113 for diet 60 SPR and 0.121 for diet 100 IM, Tab. V) suggested the latter to be lower when feeding a more diverse silage. Indeed, the ratios C14:1 c9/C14:0, C16:1 c9/C16:0 and CLA c9t11/C18:1 t11 give some measure of the activity of the $\Delta^{9}$-desaturase enzyme activity. The most reliable ratio is C14:1 c9/ C14:0 since, all C14:0 and C14:1 c9 in milk fat is produced via de novo synthesis in the mammary gland. However, conclusions based on these product/substance ratios might be erroneous due to differences in substrate concentrations as well as in affinities of the desaturase enzyme for fatty acids of different chain length. The recently described approach, based on the estimations of the intercept and slope of the linear regression fitted to milk C18:1 t11 and CLA c9t11 proportions [34], revealed the amount of C18:1 t11 converted in CLA c9t11, in the mammary gland by de novo synthesis, to be similar among diets (Tab. V).

The similar milk C18:3 n-3 concentrations despite significant differences in dietary C18:3 n-3 supply is remarkable and provoked a higher recovery of dietary C18:3 n-3 in the milk for the 60 SPP and 60 SPR diets. This higher recovery could be due to a change in rumen metabolism of C18:3 n-3, when feeding a more species diverse silage, resulting in an increased amount of C18:3 $\mathrm{n}-3$ reaching the duodenum. However, estimates of duodenal flow of C18:3 n-3 based on rumen pool size and first order rumen clearance kinetics [19] reveal the amount of C18:3 n-3 passing to the duodenum to be lower when feeding diet 60 SPR $\left(4.68 \mathrm{~g} \cdot \mathrm{d}^{-1}\right)$ or diet $60 \mathrm{SPP}\left(4.30 \mathrm{~g} \cdot \mathrm{d}^{-1}\right)$, compared to diets $100 \mathrm{IM}\left(7.81 \mathrm{~g} \cdot \mathrm{d}^{-1}\right)$ and $20 \mathrm{SPP}\left(5.13 \mathrm{~g} \cdot \mathrm{d}^{-1}\right)$. Accordingly, these data suggest a higher transfer efficiency of C18:3 n-3 from the duodenum to the mammary gland for diets 60 SPR (104\%) and 60 SPP (103\%), than for diets 100 IM $(69.6 \%)$ and 20 SPP $(94.7 \%)$. Others [4] also reported a curvilinear relation between duodenal flow of C18:3 n-3 $\left(\mathrm{g} \cdot \mathrm{d}^{-1}\right)$ and transfer efficiency from the duodenum to the milk. The reason for this varying transfer efficiency could be the necessity to maintain a certain level of milk fat plasticity by the animal [4].

It has long been recognized that medium chain fatty acids may be detrimental to human health, opposite to oleic acid and PUFAs, particularly n-3 fatty acids. The latter are known to lower blood cholesterol concentrations and hence contribute positively to human health [13]. Feeding decreasing proportions of IM silage increased the oleic acid proportion in milk and reduced medium chain fatty acids. Hence, taking together these observations, one could say that dairy products from animals fed a diverse pasture might be health promoting, due to an increased content of oleic acid and CLA c9t11 and slightly reduced concentrations of medium chain fatty acids. On the other hand, we have to be aware of the concomitant increase of $\mathrm{C} 18: 1 \mathrm{t} 11$. Indeed, consumption of trans fatty acids has been associated with an increased risk of coronary heart diseases although these associations generally do not apply to trans fatty acids of animal origin [35]. Trans-vaccenic acid has been suggested to be even health promoting due to its possible conversion to CLA c9t11 in humans [41].

\section{CONCLUSIONS}

The rumen and milk data of this study give some evidence of a partial inhibition of rumen biohydrogenation when replacing dietary intensive forage by semi-natural grassland products, resulting in a higher accumulation of biohydrogenation intermediates in the rumen and in a higher milk CLA content. 


\section{ACKNOWLEDGEMENTS}

PhD-grant of Marta Lourenço funded by the Foundation for Science and Technology, Portugal.

\section{REFERENCES}

[1] Bruinenberg M.H., Valk H., Struik P.C., The voluntary intake and in vivo digestibility of forages from semi-natural grasslands in dairy cows, Neth. J. Agr. Sci.-Wageningen J. Life Sci. 51 (2003) 219-235.

[2] Bruinenberg M.H., Valk H., Struik P.C., Fermentation and degradation in the rumen of dairy cows fed on diets consisting of silage from semi-natural grasslands, J. Agr. Sci. 142 (2004) 79-88.

[3] Chao S.C., Young D.G., Oberg C.J., Screening for inhibitory activity of essential oils on selected bacteria, fungi and viruses, J. Essent. Oil Res. 12 (2000) 639-649.

[4] Chilliard Y., Ferlay A., Mansbridge R.M., Doreau M., Ruminant milk fat plasticity: nutritional control of saturated, polyunsaturated, trans and conjugated fatty acids, Ann. Zootech. 49 (2000) 181-205.

[5] Chow T.T., Fievez V., Ensberg M., Elgersma A., De Smet S., Fatty acid content, composition and lipolysis during wilting and ensiling of perennial ryegrass, Grassland Science in Europe, Vol. IX, 2004, pp. 981-983.

[6] Chow T.T., Fievez V., Moloney A.P., Raes K., Demeyer D., De Smet S., Effect of fish oil on in vitro rumen lipolysis, apparent biohydrogenation of linoleic acid and linolenic acid and accumulation of biohydrogenation intermediates, Anim. Feed Sci. Technol. 117 (2004) $1-12$.

[7] Collomb M., Bütikofer U., Sieber R., Bosset J.O., Jeangros B., Comjugated linoleic acid and trans fatty acid composition of cows' milk fat produced in lowlands and highlands, J. Dairy Res. 68 (2001) 519-523.

[8] Collomb M., Bütikofer U., Sieber R., Jeangros B., Bosset J.O., Correlation between fatty acids in cows' milk fat produced in the Lowlands, Mountains and Highlands of Switzerland and botanical composition of the fodder, Int. Dairy J. 12 (2002) 661-666.

[9] De Brabander D.L., Raes K., Dehareng F., Geerts N.E., De Smet S., Fatty acid composition of milk fat in relation to roughage type, in: Honing Y. van der (Ed.), Book of Abstracts of the 54th Annual Meeting of the European Association for Animal Production, Rome, Italy, 2003, p. 128.

[10] Dewhurst R.J., Evans R.T., Scollan N.D., Moorby J.M., Merry R.J., Wilkins R.J., Com- parison of grass and legume silages for milk production. 2 . In vivo and in sacco evaluations of rumen function, J. Dairy Sci. 86 (2003) 2612-2621.

[11] Dewhurst R.J., Fisher W.J., Tweed J.K.S., Wilkins R.J., Comparison of grass and legume silages for milk production. 1. Production responses with different levels of concentrate, J. Dairy Sci. 86 (2003) 2598-2611.

[12] Dewhurst R.J., Scollan N.D., Lee M.R.F., Ougham H.J., Humphreys M.O., Forage breeding and management to increase the beneficial fatty acid content of ruminant products, Proc. Nutr. Soc. 62 (2003) 329-336.

[13] Dietschy J.M., Dietary fatty acids and the regulation of plasma low density lipoprotein cholesterol concentrations, J. Nutr. 128 (1998) 444S-448S.

[14] Fievez V., Vlaeminck B., Dhanoa M.S., Dewhurst R.J., Use of principal component analysis to investigate the origin of heptadecenoic and conjugated linoleic acids in milk, J. Dairy Sci. 86 (2003) 4047-4053.

[15] Folch J., Lees M., Sloanestanley H., A simple method for the isolation and purification of total lipids from animal tissues, J. Biol. Chem. 226 (1957) 497-509.

[16] Greathead H., Plants and plant extracts for improving animal productivity, Proc. Nutr. Soc. 62 (2003) 279-290.

[17] Griinari J.M., Corl B.A., Lacy S.H., Chouinard P.Y., Nurmela K.V.V., Bauman D.E., Conjugated linoleic acid is synthesized endogenously in lactating dairy cows by $\Delta^{9}$-desaturase, J. Nutr. 130 (2000) 2285-2291.

[18] Harfoot C.G., Hazlewood G.P., Lipid metabolism in the rumen, in: Hobson P.N., Stewart C.S. (Eds.), The rumen microbial ecosystem, Elsevier, London, UK, 2nd ed., 1997, pp. 382-426.

[19] Harvatine K.J., Allen M.S., Kinetic model of rumen biohydrogenation: fractional rates of fatty acid biohydrogenation and passage, J. Anim. Feed Sci. 13 (Suppl.1) (2004) 87-90.

[20] Jahreis G., Fritsche J., Kraft J., Species-dependent, seasonal and dietary variations of conjugated linoleic acid in milk, in: Yurawecz M.P., Mossoba M.M., Kramer J.K.G., Pariza M.W., Nelson G.J. (Eds.), Advances in conjugated linoleic acid research, Vol. 1, AOCS Press, Champaign, Illinois, USA, 1999, pp. 215224.

[21] Jahreis G., Fritsche J., Steinhart H., Conjugated linoleic acid in milk fat: high variation depending on production system, Nutr. Res. 17 (1997) 1479-1484.

[22] Jahreis G., Fritsche J., Steinhart H., Monthly variations of milk composition with special regard to fatty acids depending on season and 
farm management systems - conventional versus ecological, Fett-Lipid 98 (1996) 356S$359 \mathrm{~S}$.

[23] Jenkins T.C., Fellner V., McGuffey R.K., Monesin by fat interactions on trans fatty acids in cultures of mixed ruminal microorganisms grown in continuous fermentors fed corn or barley, J. Dairy Sci. 86 (2003) 324330.

[24] Kelly M.L., Berry J.R., Dwyer D.A., Griinari J.M., Chouinard P.Y., VanAmburgh M.E., Bauman D.E., Dietary fatty acid sources affect conjugated linoleic acid concentrations in milk from lactating dairy cows, J. Nutr. 128 (1998) 881-885.

[25] Kelly M.L., Kolver E.S., Bauman D.E., Van Amburg M.E., Muller L.D., Effect of intake of pasture on concentrations of conjugated linoleic acid in milk of lactating cows, J. Dairy Sci. 81 (1998) 1630-1636.

[26] Leiber F., Kreuzer M., Nigg D., Wettstein H.R., Scheeder M.R.L., A study on the causes for the elevated n-3 fatty acids in cow's milk of alpine origin, Lipids 40 (2005) 191-202.

[27] Lawson R.E., Moss A.R., Givens D.I., The role of dairy products in supplying conjugate linoleic acid to man's diet: a review, Nutr. Res. Rev. 14 (2001) 153-172.

[28] Lee M.R.F., Harris L.J., Dewhurst R.J., Merry R.J., Scollan N.D., The effect of clover silages on long chain fatty acid rumen transformations and digestion in beef steers, Anim. Sci. 76 (2003) 491-501.

[29] Lock A.L., Garnsworthy P.C., Independent effects of dietary linoleic fatty acids on the conjugated linoleic acid content of cow's milk, Anim. Sci. 74 (2002) 163-176.

[30] Loor J.J., Herbein J.H., Polan C.E., Trans 18:1 and 18:2 isomers in blood plasma and milk fat of grazing cows fed a grain supplement containing solvent-extracted or mechanically extracted soybean meal, J. Dairy Sci. 85 (2002) 1197-1207.

[31] Loor J.J., Hoover W.H., Miller-Webster T.K., Herbein J.H., Polan C.E., Biohydrogenation of unsaturated fatty acids in continuous culture fermenters during digestion of orchardgrass or red clover with three levels of ground corn supplementation, J. Anim. Sci. 81 (2003) 1611-1627.

[32] Loor J.J., Ueda K., Ferlay A., Chilliard Y., Doreau M., Diurnal profiles of conjugated linoleic acids and trans fatty acids in ruminal fluid from cows fed a high concentrate diet supplemented with fish oil, linseed oil, or sunflower oil, J. Dairy Sci. 87 (2004) 2468-2471.

[33] Ørskov E.R., McDonald I., The estimation of protein degradability in the rumen from incubation measurements weighed according to rate of passage, J. Agr. Sci. 92 (1979) 499503.

[34] Palmquist D.L., St-Pierre N., McClure K.E., Tissue fatty acid profiles can be used to quantify endogenous rumenic acid synthesis in lambs, J. Nutr. 134 (2004) 2407-2414.

[35] Parodi P.W., Milk fat in human nutrition, Aust. J. Dairy Technol. 59 (2004) 3-59.

[36] Raes K., De Smet S., Demeyer D., Effect of double-muscling in Belgian Blue young bulls on the intramuscular fatty acid composition with emphasis on conjugated linoleic acid and polyunsaturated fatty acids, Anim. Sci. 73 (2001) 253-260.

[37] Raes K., Haak L., Balcaen A., Claeys E., Demeyer D., De Smet S., Effect of linseed feeding at similar linoleic acid levels on the fatty acid composition of double-muscled Belgian Blue young bulls, Meat Sci. 66 (2004) 307-315.

[38] Rowe A., Macedo F.A.F., Visentainer J.V., Souza N.E., Matsushita M., Muscle composition and fatty acid profile in lambs fattened in drylot or pasture, Meat Sci. 51 (1999) 283288.

[39] Santos-Silva J., Bessa R.J.B., Santos-Silva F., Effect of genotype, feeding system and slaughter weight on the quality of light lambs. II. Fatty acid composition of meat, Livest. Prod. Sci. 77 (2002) 187-194.

[40] Taweel H.Z., Tas B.M., Dijkstra J., Tamminga $S$., Intake regulation and grazing behaviour of dairy cows under continuous stocking, J. Dairy Sci. 87 (2004) 3417-3427.

[41] Turpeinen A.M., Mutanen M., Antti A., Salminen I., Basu S., Palmquist D.L., Griinari J.M., Bioconversion of vaccenic acid to conjugated linoleic acid in humans, Am. J. Clin. Nutr. 76 (2002) 504-510.

[42] Van Es A.J.H., Feed evaluation for ruminants. I. The system in use from May 1977 onwards in The Netherlands, Livest. Prod. Sci. 5 (1978) 331-345.

[43] Van Nevel C., Demeyer D.I., Lipolysis and biohydrogenation of soybean oil in the rumen in vitro: Inhibition by antimicrobials, J. Dairy Sci. 78 (1995) 2797-2806.

[44] Van Vuuren A., Krol-Kramer F., Van Der Lee R.A., Corbijn H., Protein digestion and intestinal amino acids in dairy cows fed fresh Lolium perenne with different nitrogen contents, J. Dairy Sci. 75 (1992) 2215-2225.

[45] Vlaeminck B., Dufour C., Van Vuuren A.M., Cabrita A.R.J., Dewhurst R.J., Demeyer D., Fievez V., Potential of odd and branched chain fatty acids as microbial markers: evaluation in rumen contents and milk, J. Dairy Sci. 88 (2005) 1031-1042. 